\title{
Scrapmelting Process in Steelmaking Converter Using Coke Bed
}

\author{
Takeyuki HIRATA, Hiroaki IsHIDA and Shouji ANEZAKI
}

\section{Synopsis :}

A steel production process with $100 \%$ scrap using a combination-blown converter was developed to utilize small converters, which tend to be out of operation under recent economical situations, and to improve flexibility of steel production. This process does not use hot metal. Instead of hot metal, it utilizes coke bed, which is formed initially on the bottom of a converter. It uses only coke as fuel, and uses nearly the same facilities as an ordinary steelmaking converter.

Experimental results in a converter for a $10 \mathrm{t}$ melt were as follows :

(1) Bottom blow equipment for oxygen was indispensable for this process. However, requisite ratio of bottom blow oxygen was $15 \%$. The same facilities as a steelmaking converter were confirmed to be usable.

(2) The ratio of initially charged coke to the total amount of coke affected the whole heat efficiency of this process. When the ratio increased, perfect burning of coke promoted naturally. The higher the ratio, the lower the consumption of coke.

It was thought that the bottom blow oxygen was necessary to improve the reaction ratio of oxygen with coke, and that the effect of the initially charged coke was in agreement with thermodynamical conditions. Key words : steelmaking; coke; scrap ; converter; post combustion; flexibility.

\section{1. 緒言}

鉄鋼業には, 生産量により収益が大きく影響される体 質がある．激しい経済情勢の変動に対応するためには， 今後いっそう柔軟な生産構造に変革していかねばならな い.また，厳しい国際競争に勝ち抜くためには生産の集 約も図らねばならず，比較的規模の小さい転炉が休止さ れる傾向にある．これらの転炉の活用を図ることは重要 な課題である.

一方原料面から見ると, 年々老廃スクラップの発生量 が増えている. しかし対粗鋼スクラップ原単位は上昇し ているにもかかわらず, 転炬におけるスクラップ消費量 は減少している1).これは溶銑予備処理の普及に一因が あるが, 電気炉との競争・共存も考慮に入れて, 転炉の スクラップ消費のあり方を再検討すべき時期にきている と考える.

これらの状況を踏まえて, 著者らは転炬でのスクラッ プ使用量の増加方法をまず検討した，転炉に溶銑と共に
くから行われてきた ${ }^{23)}$. また最近でも，KS/KMS 法の ように底吹き羽口から微粉炭を吹き込み，かつ二次燃焼 率を高めて燃料原単位を下げる方法や4)，KVA 法のよ うに天然ガスをバーナーのように使う方法5) などが開発 されている. しかし著者らは，設備やプロセスの柔軟性 をいっそう重視し，単純な設備で通常の製鋼用転炬と互 換性があること，溶鉄が無くても操業できること，しか も極力燃料原単位を低くできること等が必要と考えた。 そして製鋼用の複合吹錬転炉を用い，溶鉄の代わりに コークスベッドを活用する, 新しいスクラップ溶解法の 開発に着手した6) ${ }^{6)}$.

従来の, 溶銑と共にコークスを使用する方法と比較し つつ,この方法によるスクラップの溶解結果と特性を以 下に報告する.

\section{2. 実 験 方 法}

実験には $10 \mathrm{t}$ 試験転炉を用いた. Table 1, Fig. 1 に, それぞれの実験条件および設備概要を示す。

転炉の炉内容積は，れんが積み直後には $5.6 \mathrm{~m}^{3}$ だっ コークスを入れて, スクラップ使用率を高める方法は古 昭和 60 年 10 月本会講演大会にて発表 平成 2 年 3 月 9 日受付 (Received Mar. 9, 1990)

* 住友金属工業(株)鉄鋼技術研究所 (Iron \& Steel Research Laboratory, Sumitomo Metal Industries, Ltd., 3 Oaza-Hikari Kashimamachi Kashima-gun Ibaraki pref. 314)

*2 住友金属工業(株)鉄鋼技術研究所 工博（Iron \& Steel Research Laboratory, Sumitomo Metal Industries, Ltd.) 
たが，実験回数を重ねるにつれて大きくなり，最終的に は2 倍程度に広がった. 酸素は主として上吹きランスか ら供給したが，底吹き羽口も補助的に使用した，上吹き ランスの先端位置は, 炉口高さ近辺を中心にして, 炉内 へ $1 \mathrm{~m}$ 程度までの範囲とした。コークスには, 高炉用 の小サイズ品を使い，乾燥等の事前処理はしなかった.

付着水分は，実験の都度測定したが，おおむね 3 5\% だった．スクラップには製鉄所内で発生するビレットや ブルームの切断くずを用いた．炉上からは投入できな かったため, 専用シュートにより通常の実用転炉と同様

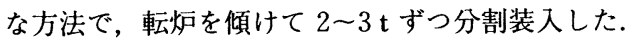

実験手順は，まず転炉を約 $20 \mathrm{~h}$ かけてれんが表面が $1000^{\circ} \mathrm{C}$ になるまで予熱した，次に，炉上からコークス を $400 \sim 1200 \mathrm{~kg}$ 投入し, 底吹き酸素 $200 \sim 400 \mathrm{Nm}^{3} / \mathrm{h}$

Table 1. Experimental conditions.

\begin{tabular}{l|l}
\hline \multicolumn{1}{c|}{ Item } & \multicolumn{1}{c}{ Content } \\
\hline Volume & $5.6 \mathrm{~m}^{3}$ (After lining) \\
\hline Top-blown oxygen & $\begin{array}{l}\text { Number of lance nozzles }: 6 \\
\text { Jet direction }: 10^{\circ} \text { from the vertical } \\
\text { Flow rate }: 1000 \sim 1400 \mathrm{Nm}^{3} / \mathrm{h}\end{array}$ \\
\hline Bottom-blown oxygen & $\begin{array}{l}\text { Number of tuyers }: 2 \sim 4 \\
\text { Flow rate }: 0 \sim 800 \mathrm{Nm}^{3} / \mathrm{h}\end{array}$ \\
\hline Coke & $\begin{array}{l}\text { Consumption }: 1 \sim 3 \mathrm{t} / \mathrm{heat} \\
\text { Size }: 20 \sim 25 \mathrm{~mm} \text {. } \\
\text { Chemical composition }(\mathrm{wt} \% \text { ) } \\
\text { Fixed-C Accompanied } \mathrm{H}_{2} \mathrm{O} \\
88 \quad 11.4 \quad 3 \sim 5\end{array}$ \\
\hline Scrap & $\begin{array}{l}\text { Consumption }: 7 \sim 10 \mathrm{t} / \mathrm{heat} \\
\text { Size : about } 200 \times 200 \times 200 \mathrm{~mm} \\
\text { (Crop ends from billets and blooms) }\end{array}$ \\
\hline
\end{tabular}

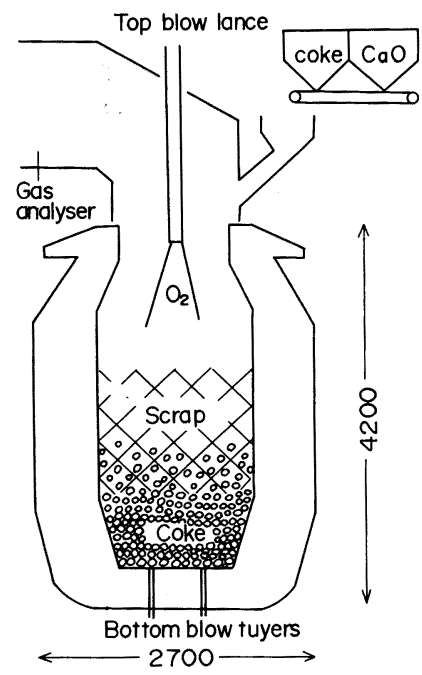

Fig. 1. Schematic drawing of an experimental combination-blown steelmaking converter for a $10 \mathrm{t}$ melt.
で着火させた。コークスの表面が赤くなってから 1 回目 のスクラップを装入し，底吹き酸素に加えて上吹き酸素 $500 \sim 600 \mathrm{Nm}^{3} / \mathrm{h}$ も使用した. 2 回目のスクラップは数 分後に送酸を中断し，炬傾動をして装入した。この後も 同様な操作を繰り返し，所定量のスクラップが入り終 わった段階で酸素供給速度を全体で $1200 \sim 1800 \mathrm{Nm}^{3} / \mathrm{h}$ に上げ，本格的なスクラップ溶解工程を開始した．実験 条件によりコークスを追加する場合には，送酸を継続し たまま $100 \mathrm{~kg} / \mathrm{min}$ の速さで, 炉上から連続的に投入し た. 炉の予熱完了からスクラップの装入完了までの時間 は, スクラップシュートの吊り替えに伴う酸素供給停止 時間も含めて, $40 \mathrm{~min} \sim 60 \mathrm{~min}$ だった。

本格的な溶解工程に入った後は，後方煙道に設けた排 ガス分析計 $\left(\mathrm{CO}\right.$ および $\mathrm{CO}_{2}$ は赤外線式, $\mathrm{O}_{2}$ は磁気式 $)$ によりコークスの燃焼状況を刻々監視し，炉内状況を推 定すると共に, 適時に炉内観察を行ってコークス残留量 やスクラップの溶解状況をチェックした。 また耐火物保 護の観点から, スラグ中の $\mathrm{CaO}$ と $\mathrm{SiO}_{2}$ の重量比が 2 になるように，コークス燃焼量に合わせて生石灰を炉上 から連続的に投入した。この溶解工程には, 通常 $30 \mathrm{~min}$ 〜60 min を要した.

以下のデータ中, 特に断らない限り, コークス重量は 付着水分込みであり, コークス原単位はスクラップ装入 $\mathrm{t}$ あたりで，スクラップ溶解完了時点でのメタル性状を $1500^{\circ} \mathrm{C}$, [ C ] $=2.5 \%$ に統一したときの值を表す.

\section{3. 実 験 結 果}

\section{$3 \cdot 1$ 溶解結果}

Table 2 に本法での溶解結果を示す. 脱硫・脱窒を考 えて, 溶解後の [ C ] は $2.5 \%$ 以上とした. 溶解後の目 視観察で炉内にコークスがほとんどなくても，[ C ] は 確保できた. [ P ] はスクラップ中の [ P ] が低く, 炉 内インプット量が少ないために低レベルになった．脱硫 は, 実操業では炉外でも可能だが，ここでは加炭あるい は $\mathrm{Al}$ 添加により行った. その後除涬し,引き続き脱炭 した. [N] は脱炭に伴って通常の溶銑を用いたときと 同程度まで下がり，鋼質としては総じて通常の転炬鋼な みのものを得ることができた.

\section{$3 \cdot 2$ 炉内のガス発生状況}

Fig. 2 に，本法に扔いてスクラップ装入前にコークス を全量炉内に投入したときの排ガス発生状況の一例を示 す. 炬口からの空気巻込みの影響は, 後方煙道での排ガ ス分析値を，酸素の物質バランスにより補正して排除し た. 本実験条件では, 溶解工程の前半には CO は発生 しなかった。この期間の長さは実験条件により変化した 
Table 2. Metal temperature and chemical composition.

\begin{tabular}{|c|c|c|c|c|c|c|}
\hline & Temp. $\left({ }^{\circ} \mathrm{C}\right)$ & {$[\mathrm{C}] \%$} & {$[\mathrm{P}] \%$} & {$[\mathrm{~S}] \%$} & {$[\mathrm{~N}] \%$} & $(\mathrm{~T} . \mathrm{Fe}) \%$ \\
\hline $\begin{array}{l}\text { At melt-down } \\
\text { After desulfurization and decarburization }\end{array}$ & $\begin{array}{l}1500 \sim 1600 \\
1630 \sim 1680\end{array}$ & $\begin{array}{l}2.5 \sim 4.0 \\
0.03 \sim 0.08\end{array}$ & $\begin{array}{l}0.005 \sim 0.015 \\
0.008 \sim 0.012\end{array}$ & $\begin{array}{l}0.080 \sim 0.120 \\
0.010 \sim 0.004\end{array}$ & $\begin{array}{l}0.007 \sim 0.014 \\
0.001 \sim 0.002\end{array}$ & $\begin{array}{c}5.0 \sim 12.0 \\
10.0 \sim 15.0\end{array}$ \\
\hline
\end{tabular}

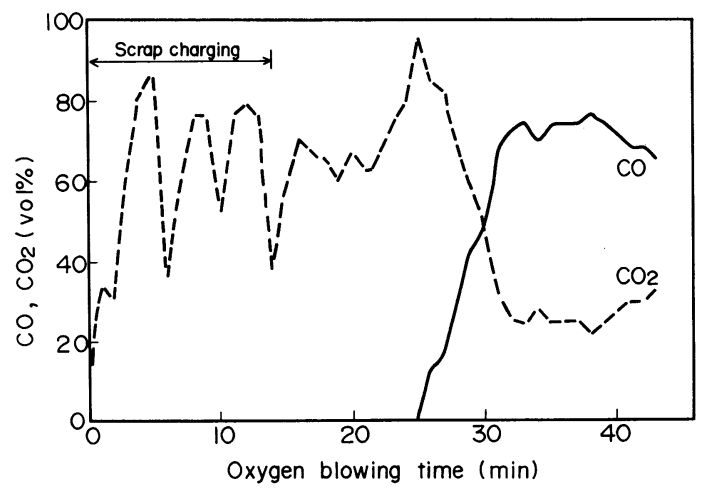

Fig. 2. Changes in gas composition in the experimental converter during scrap melting without hot metal.

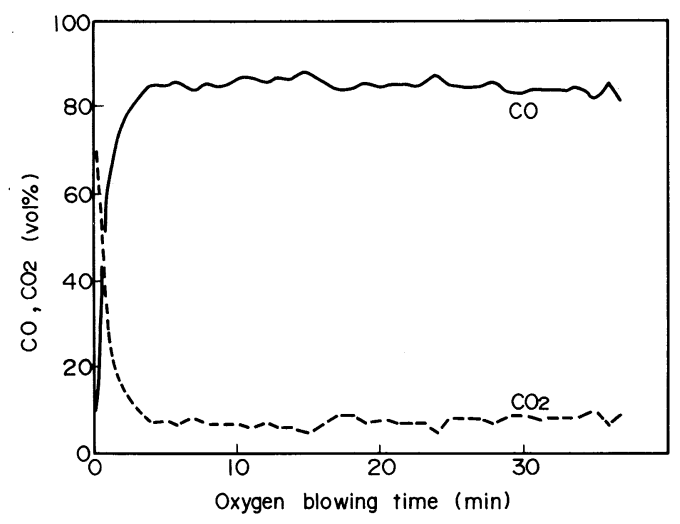

Fig. 3. Changes in gas composition in the experimental converter during scrap melting with hot metal by a convention process.

が, 各実験に共通してこの間の炉内反応は穏やかだった. 後半になって $\mathrm{CO}$ が出始めると, ダストの発生量が多 くなり，スピッティングが観察されるなど，外観的にし だいに溶銑を用いる通常の製鋼吹錬に近づいた.

一方 Fig. 3 には，比較のために従来の方法で，溶鉄 にコークスを加えつつスクラップを溶かした場合の操 業結果を示す．この操業条件は, $10 \mathrm{t}$ 転炉においてスク ラップ $5 \mathrm{t}$ に溶銑 $5 \mathrm{t}$ を加え，上吹き酸素 $1200 \sim 1600$ $\mathrm{Nm}^{3} / \mathrm{h}$ で吹錬したものである.このような条件では吹 鍊時間は長くなったが, ガス発生状況は通常の場合 ( ス

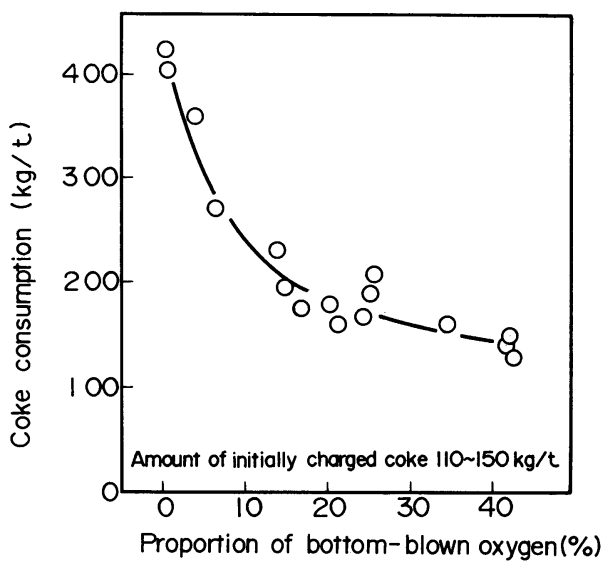

Fig. 4. Influence of proportion of bottom-blown oxygen on coke consumption up to the melt-down.

クラップ使用量 $1 \mathrm{t}$ 程度）と同様で, 吹錬開始後少し遅 れて $\mathrm{CO}$ が出始め, 以後 $\mathrm{CO}$ が中心になって継続的に 発生した. 吹鍊の状況も通常の場合と変わらなかった.

\section{$3 \cdot 3$ コークス原単位におよぼす操業条件の影霎}

本法において通常の複合吹錬転炉との互換性を重視し ても，底吹き酸素の供給能力についての指針は必要であ る.コークスの投入条件を一定にして, 底吹き酸素の供 給条件が本法に与える影響を調査した，底吹き酸素流量 が多すぎると，コークスが炬外へ飛び出すことがあり， 飛び出さない範囲で実験を行った．

Fig. 4 に，スクラップ装入前に入れたコークス量 (以 下，初装入コークス量とする）を，スクラップ $1 \mathrm{t}$ 当た り $110 \sim 150 \mathrm{~kg} に し$, 残りは溶解工程中心に分割投入し たときの, 酸素底吹き比率 (底吹き酸素使用量/全酸素 使用量）がコークス原単位に与える影響を示す.

$10 \mathrm{t}$ 転炉では，酸素底吹き比率が $15 \%$ 付近までは, $1 \%$ 上昇するとコークス原単位が $15 \mathrm{~kg} / \mathrm{t}$ 減少する大き な効果があった．この間で酸素底吹き比率が低いほど, 酸素供給開始後に 5 10 min，未反応酸素が排ガス中に 残留する傾向があった. $15 \%$ より底吹き比率が高い条 件では, 排ガス中の未反応酸素は酸素供給開始後 $5 \mathrm{~min}$ 以内に解消し, 底吹き比率の上昇効果は $1 \%$ あたりコー クス原単位 $1 \sim 2 \mathrm{~kg} / \mathrm{t}$ の減少になった.

Fig. 5 に初装入コークス比率 (初装入コークス量/全 
装入コークス量）がコークス原単位に与える影響を示 す.ここでの酸素底吹き比率については，Fig. 4 で変化 の影響が少なかった，15〜45\%の範囲のデー夕を記入 した．初装入コークス比率を $1 \%$ 上げると，コークス原 単位が $1.3 \mathrm{~kg} / \mathrm{t}$ 下がる効果があるとわかった. 初装入 コークス比率を変えることは設備的対応を特に必要とし ないため, 広範囲にわたる調査が可能で, 全体としては $130 \mathrm{~kg} / \mathrm{t}$ にも及ぶ大きな影響を確認した.

Fig. 6 に，スクラップ装入開始から溶解完了までの 1 ヒート平均の完全燃焼率と初装入コークス比率との関係 を示し, Fig. 7 には, Fig. 6 に対応させて, 熱効率と初 装入コークス比率との関係を示す. 完全燃焼率および熱 効率は次のように定義した.

完全燃焼率 $=\left\{\mathrm{CO}_{2} \% /\left(\mathrm{CO} \%+\mathrm{CO}_{2} \%\right)\right\} \times 100$

熱効率 $=\left\{\right.$ 溶銑含熱量 $/ \mathrm{CO}$ と $\mathrm{CO}_{2}$ の発熱量 $\} \times 100$

初装入コークス比率を高めると, 完全燃焼率は上昇し

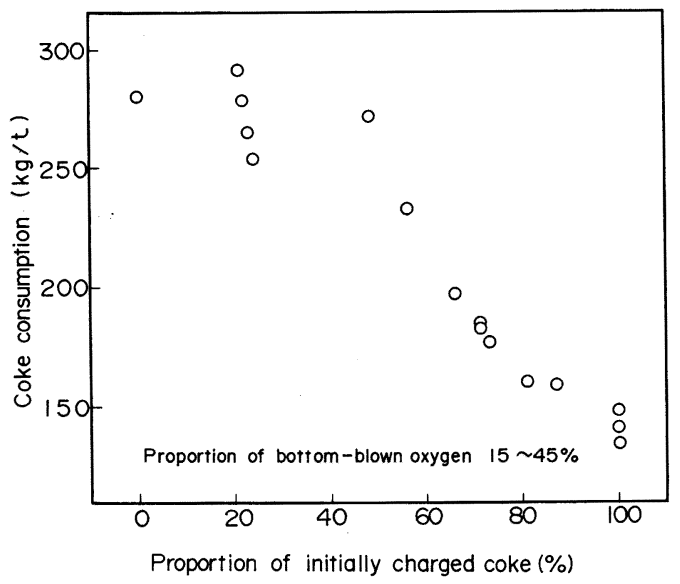

Fig. 5. Influence of proportion of initially charged coke on coke consumption up to the melt-down.

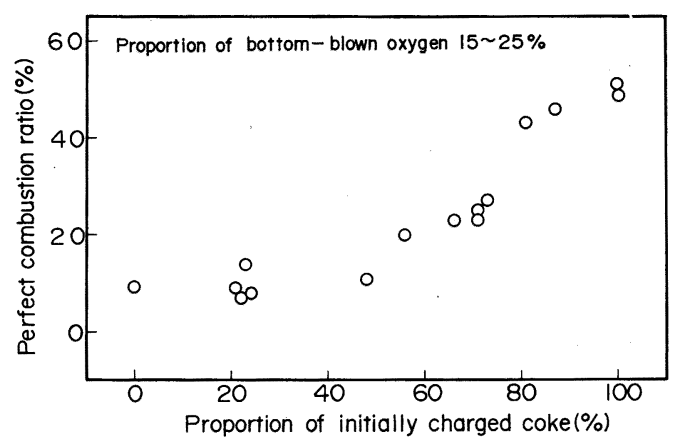

Fig. 6. Perfect combustion ratio as affected by the proportion of initially charged coke.

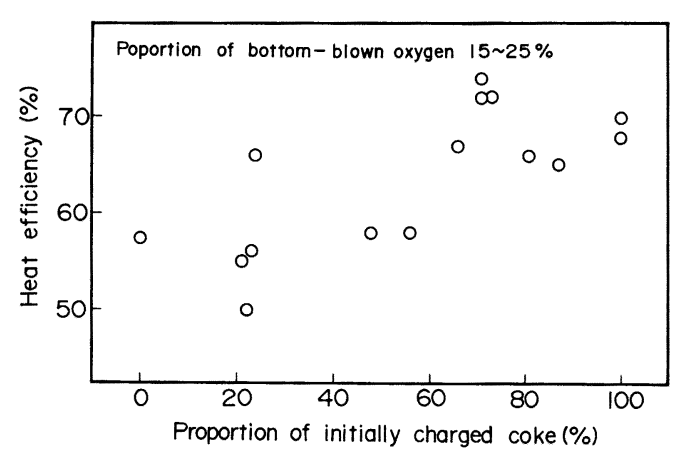

Fig. 7. Heat efficiency as affected by the proportion of initially charged coke.

た. しかも熱効率も，上昇傾向にあった。したがって， 初装入コークス比率の上昇によるコークス原単位の減少 効果は, 主としてコークスの完全燃焼率が高まることに 原因があるが，この高い熱発生量をスクラップに有効に 伝えることができる点で, 伝熱機構も良好なためとわ かった。

\section{$3 \cdot 4$ 従来法と本法とのコークス原単位の比较}

転炬製鋼法のスクラップ使用比率 \{スクラップ量/( ス クラップ+溶鉄量) \}は平均 $10 \%$ 程度であり,これにコー クスを熱源として加えてスクラップ使用比率を高める方 法は, 昔から行われてきた.この方法を以後, 従来法と 呼ぶ.この従来法においても，初装入のスクラップおよ び溶銑量を共に減らして吹錬を始め, 以後スクラップと コークスとを適当に加えつつ吹錬を続ければ，理屈上限 りなくオールスクラップ操業に近づく.

Fig. 8 には, 先行文献データ ${ }^{2)}$ を含めて, 従来法での スクラップ使用率とコークス原単位との関係を示す. 図 中には, 比較のために本法のコークス原単位も併記した. この図に限り,コークス原単位はスクラップと溶銑との 合計重量に対する原単位を表す，従来法では，広範囲に わたってみかけ上直線的関係 (スクラップ使用比率 $3 \%$ あたりコークス原単位 $10 \mathrm{~kg} / \mathrm{t}$ ) があった。 しかし本法 のコークス原単位は，その直線的関係をスクラップ使用 比率 $100 \%$ まで外挿した值より低かった.

\section{4. 考察}

\section{$4 \cdot 1$ 溶解進行経過の推定}

従来法では, Fig. 3 に示したように，酸素供給期間の 初期から CO が発生した。これは通常の転炉吹錬と同 様であり，上吹き酸素は最初から溶銑と反応して高温の 火点を形成し，溶銑を加熱する.そしてスクラップは, 加熱された溶銑に徐々に溶かされていくと考えられる. 


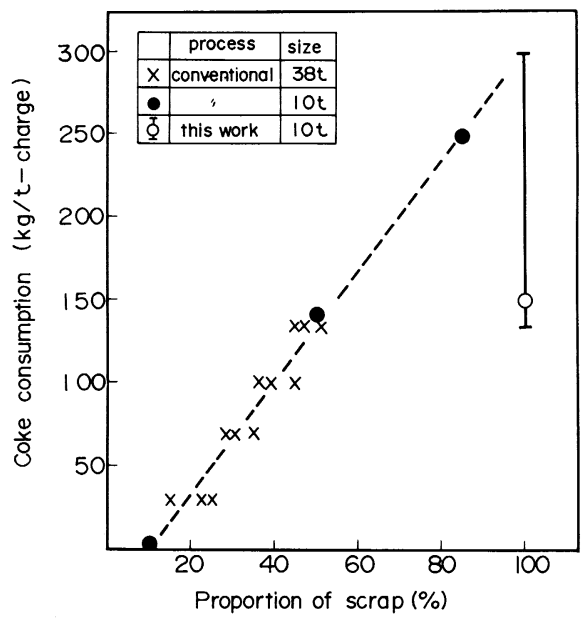

$X$ : After Aoyama ${ }^{2)}$

Fig. 8. Consumption of coke per total weight of scrap and hot metal related to proportion of scrap and scrapmelting process.

しかし本法では，装入物はすべて常温からスタートし ている.酸素はまず衝突点でコークスと反応し,そのコー クスを加熱した後，排ガスとなって周用のスクラップお よびコークスを一緒に加熱する。しかしある段階からは 溶融物ができて, 従来法と類似の溶解プロセスに移行す ると考えられる. そこでどの時点から溶解が進行してい るのかを, $10 \mathrm{t}$ 転炉で $\mathrm{Cu}$ をトレーサーにして調査した。 このときの初装入コークス比率は 40～50\%である.

Fig. 9 に，酸素供給時間全体の中の経過時間率とスク ラップの溶解比率との関係を示す。溶解比率は後半に なってから上昇しており，前半には溶融物は存在しな かった。これは従来法のように初期から局所的に高温部 ができるのではなく，コークスを含めて全体が徐々に加 熱された後, スクラップが溶け始めたことを示している.

\section{$4 \cdot 2$ 酸素底吹き比率の上昇効果}

Fig. 4 に示したように, 本法では酸素底吹き比率を上 げるとコークス原単位が減少した．特に底吹き比率 $15 \%$ 付近までは酸素底吹き比率の上昇効果が大きかっ たが，これは酸素供給開始後に排ガス中に未反応酸素が 混じる期間が, 底吹き比率上昇に伴って短くなったこと に関係すると考えられる。

本法の送酸初期において, 底吹き酸素は上吹き酸素に 比べて次の特長があると考えられる。

(1)初期には, 底吹き酸素の方がコークスとの反応効 率が高い.

本法では，初期に多量のコークスを炉内に投入するた

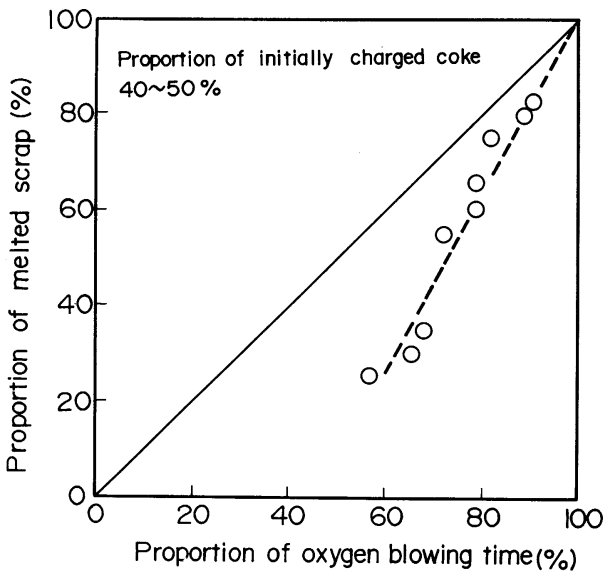

Fig. 9. Course of proportion of melted scrap.

め，コークスは炉底に多く存在する. しかし初期にはス クラップも多いために，上吹き酸素は十分には炉底まで 到達せず，コークスとの反応率が不十分になる。

(2) 上吹き酸素だけより酸素供給路を増やし，熱効率 を高める。

上吹き酸素は，耐火物溶損防止の観点からそのジェッ トの広がり角度を制限する必要があり，炉壁近傍の装入 物を加熱しにくい。しかし底吹き酸素なら，適正な羽口 配置により可能である．また，均一に炉内を加熱する上 でも，酸素供給路は多い方が都合がよい.

しかし溶解期の後半には, 炉内装入物の高さが下がり, かつ全体に温度が上がるために，上吹き酸素に対する底 吹き酸素の特長が薄れる．特に溶鉄が炬底にたまった後 では，底吹き酸素は溶銑と反応して COになり，全体 としての完全燃焼率を下げるために，かえって都合が悪 w.

本実験条件では，酸素底吹き比率 $15 \%$ 付近を境にし て，底吹き比率の上昇がコークス原単位におよぼす影響 に変化があった．15\% までは送酸初期に酸素反応効率 を改善する効果の影響が強く，15\% 以上では酸素反応 効率の方は十分になり，熱効率や完全燃焼率変化の影響 が強くなった結果と考えられる．

酸素底吹き比率を上げることは，コークス原単位の減 少の外，設備的負担の増加や，底吹きによるコークスお よび溶融物の飛び出しも伴う。このためこの比率には, 転炉形状等の操業条件に応じて適切な值があると考えら れる.

\section{$4 \cdot 3$ 熱効率}

Fig. 6，7 に示したように，酸素底吹き比率 15～25\% 


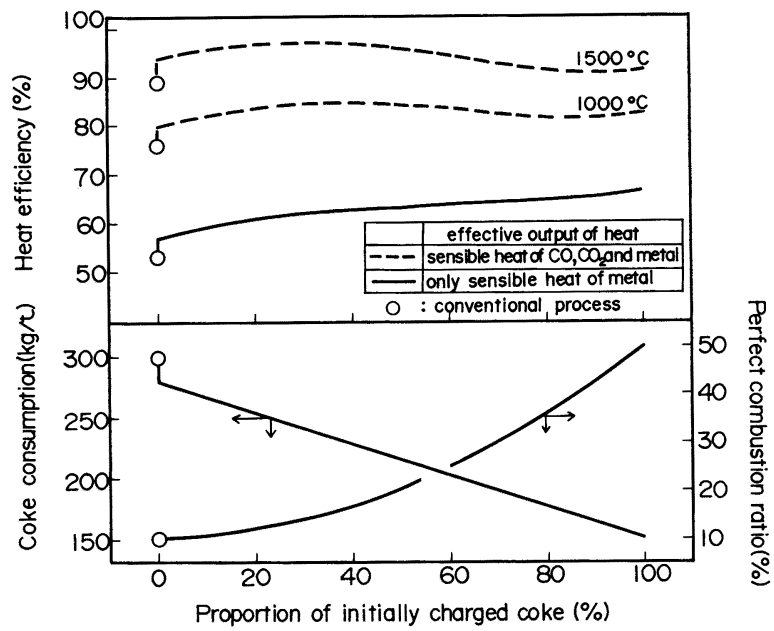

Fig. 10. Effect of change in temperature of exhaust gas on calculated heat efficiency related to proportion of initially charged coke. Perfect combustion ratio and coke consumption are assumed to be as shown in the lower part of this figure.
では初装入コークス比率を上げると完全燃焼率が高ま り，同時に熱効率も高まる傾向があった．ただしこの熱 効率は溶鉄の含熱量のみを有効とし，排ガスのもって逃 げる顕熱や潜熱が変化することの影響は考慮しなかっ た．本法の目的がスクラップの効率的溶解にあり，排ガ ス顕熱やその潜熱の利用は対象外のためである.しかし 初装入コークス比率の上昇に伴って排ガス発生量が隇少 し，かつその組成も変化している. 全体の熱効率を考え る上では，排ガス顕熱の熱効率への影響を把握しておく ことは有用である. Fig. 10 に，この影響を計算により 示す.

Fig. 10 下部のように，コークス原単位と完全燃焼率 とを実験結果に基づいて模式化した，実際の燃焼カーボ ン量が，メタルの [ C ] 上昇およびダストロスにより， 炉内投入量より平均的に $30 \mathrm{~kg} / \mathrm{t}$ 少ないことを考虑する と，Fig. 10 上部のように熱効率が定まる.この実線は Fig. 7 に示したと同じ，溶鉄含熱量のみを考慮した熱効 率であるが, 破線はおのおの $1500^{\circ} \mathrm{C}, 1000^{\circ} \mathrm{C}$ を仮定 した排ガスの顕熱も有効側に入れてある.

他に考慮すべき熱量には，炉体への蓄熱，スラグ, 羽 口保護ガス $\left(\mathrm{N}_{2}\right)$ 等がある. 炉体への熱ロスは溶融メ タルの存在時間に比例するとして，炉体への熱ロスを Fig. 9 のような溶解推移, および溶解完了後の送酸停止 中メ夕ル温度の低下速度 $\left(8 \sim 10^{\circ} \mathrm{C} / \mathrm{min}\right)$ 加求め, ス ラグおよび羽口保護ガス等への熱ロスをスラグの含熱量 $(1883 \mathrm{~J} / \mathrm{g})$ や各物質の比熱 ${ }^{9)}$ から求めると, これらの 熱口スの合計は, 初装入コークス比率に関係なく全発熱 量の 12 15\%になった. Fig. 10 の熱バランスから考え ると, 本法における排ガスの平均温度は, 初装入コーク ス比率にかかわらず $1200^{\circ} \mathrm{C}$ 程度になる.
本法では，スクラップ全量を最初に炉内に装入するた めに, Fig. 9 からわかるように，それらが加熱前半には 積み重なったまま存在する。このため燃焼ガスとスク ラップとの熱交換率が良い. しかも初装入コークス比率 を高めることにより完全燃焼率が上昇し, 排ガス発生量 が滅少している.この間, 排ガスの平均温度は $1200^{\circ} \mathrm{C}$ 程度と一定であることから，排ガスへの熱ロスは減少し ていると分かった。

溶鉄にスクラップを溶かし込む従来法との比較では, 従来法の溶鉄温度は常時 $1400 \sim 1500^{\circ} \mathrm{C}$ あり，排ガス 温度は $1400^{\circ} \mathrm{C}$ 以上あると考えられる. しかもコーク スの完全燃焼率は $10 \%$ 程度と低いためにガス発生量が 多く,排ガスへの熱口スは本法よりも多いと考えられる.

このように本法は，スクラップとガスとの熱交換率お よび排ガス発生量の両面で, 熱効率的に従来法より優れ ていると考えられる.

\section{$4 \cdot 4$ 完全燃焼率向上とコークス原単位の低減}

熱力学的には, コークスに酸素を吹き付けると, 低温 では $\mathrm{CO}_{2}$ が, 高温では $\mathrm{CO}$ が発生する.この境界は約 $705^{\circ} \mathrm{C}$ である. ただしコークスが無い条件 (炉内上部等) では CO の二次燃焼が考えられるため, 酸素の供給方 法の影響を受け得る。しかしいずれにしろ，炉内が低温 ほど $\mathrm{CO}_{2}$ になりやすく，コークス原単位を低減する上 で有利であると考えられる。

Fig. 11 には, Fig. 2 に対応して, 溶解時間の進行に 伴う完全燃焼率および炬内平均温度の推移の計算結果を 示す. 温度の推定にあたっては, 溶解の全期間にわたっ て一定の熱効率（このヒートの平均熱効率＝71\%）を用 い, $20 \mathrm{~s}$ ごとに物質バランス, 各物質の比熱, 酸化発 熱量を求めて, 炉内装入物の平均温度を算出した。実際 


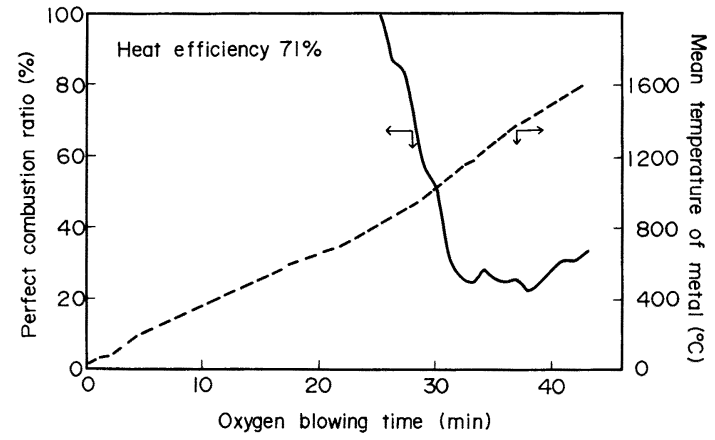

Fig. 11. Courses of perfect combustion ratio and estimated mean temperature in the converter. Heat efficiency was assumed to be almost constant during whole oxygen blowing time.

には，送酸初期には炉内装入物の温度が低いこと，およ び炉内装入物の積層構造の影響から熱効率は平均より高 く, 送酸末期には逆に熱効率は平均より低くなるという 変化が考えられる.このため初期の炬内平均温度の上昇 速度は，実際には Fig. 11 よりも速い可能性がある.

ヒート平均の完全燃焼率を上げるには，初期炉内の低 温を利用し, 前半の $100 \%$ の期間を長くすることが効果 的だった. Fig. 11 では, 完全燃焼率が下がり始める時 点での炉内平均温度は, 実際の熱効率変化も考慮すると $800^{\circ} \mathrm{C}$ 以上と考えられた。この場合, コークスの初期装 入比率は $100 \%$ であり，コークスも含めて $800^{\circ} \mathrm{C}$ まで は完全燃焼による加熱の恩恵に浴することができたとい える.

従来法のように初めから溶銑を入れると, 酸素は主に 溶銑と反応して CO になってしまう.したがって $\mathrm{CO}_{2}$ の形成は二次燃焼に頼ることになるが，この効率を安定 して高めることは, 転炉の実操業例から見てなかなか困 難である ${ }^{10) 11)}$. 本法では, 比較的低温度での自然な完 全燃焼を活用する点で，耐火物への悪影響を抑えつつ全 体の発熱効率を高めることが可能であり，スクラップへ の着熱効率も従来法より有利な結果, コークス原単位 $150 \mathrm{~kg} / \mathrm{t}$ (カーボン原単位換算で $127 \mathrm{~kg} / \mathrm{t}$ ) という良好 な結果が得られていると考える.

\section{5. 結言}

スクラップ発生量の増加に対処し, 転炉をいっそう活 用するための一方法として, 転炉によるスクラップ溶解 法を考案した.この特徴は, 複合吹錬転灯でコークスベッ
ドを活用し，溶銑は一切使わない点にある．また生産の 柔軟化を指向しており，通常の製鋼用転炬との互換性も 重視している.

この方法を $10 \mathrm{t}$ 試験転炉で実験した結果，次の結論 を得た。

( 1 )脱硫は別途行う必要があったが, 製鉄所内で発生 するスクラップを溶解することにより, 総じて通常の転 炉鋼並みの溶鋼が得られた。

(2)必要設備としては, 酸素を全酸素使用量の $15 \%$ 程度底吹きするだけであり，通常の複合吹鍊転炉を流用 できることが確認できた。

(3)操業上は, 酸素底吹き比率 $15 \%$ 以上を確保した 上で, コークスの初期装入比率を増やすことが，コーク ス原単位の低減に最も大きな効果があった.

(4)本法の溶解進行過程は, 常温状態からコークスと 酸素とが反応し，コークス自体およびスクラップを徐々 に全体的に加熱する. その後溶銑が形成され，以後はそ の溶銑と酸素とが反応する, 通常の転炉吹鍊に近いプロ セスに移行するものと考えられた。

( 5 )底吹き酸素は, 初期装入コークスと酸素との反応 率を高めるために必要であり,コークスの初期装入比率 の増加は, 初期炉内の低温状態を活用し, 平均完全燃焼 率を高めるのに効果があると考えられた.

(6)本法によれば, いわゆるソフトブロー等の二次燃 焼率を高める操作をしなくても, 自然に完全燃焼率が高 まる. しかも熱効率も炉内構造に基づいて高いために, 溶銑にスクラップを溶かし込む従来法より効率的な操業 が可能になると考える.

\section{文献}

1) 林 高朗: 鉄鋼界, 38 (1988) 8, p. 29

2) 青山芳正, 白井弘治, 松永 昭: 鉄と鋼, 48 (1962), p. 1363

3 ）松永吉之助, 古賀敬造, 中谷元彦: 鉄と鋼, 50 (1964), p. 403

4 ) $L$. V. Bogdandy, $K$. Schaefer, $K$. Brotzmann and $H$. G. GECK: Stahl Eisen, 104 (1984), p. 1143

5 ) L. V. Bogdandy, G. MitTER, A. Moser and $O$. KoEller: BHM, 134 (1989), p. 203

6 ) 丸川雄浄, 姉崎正治, 平田武行: 鉄と鋼, 71 (1985), S 930

7 ) 多賀雅之, 丸川雄浄, 姉崎正治, 平田武行, 石田博章: 鉄と鋼, 73 (1987), S 916

8 ) 石田博章, 丸川雄浄, 姉崎正治, 平田武行, 塩出純孝: 材料とプロセス, 1 (1988), p. 245

9 ）溶鉄·溶滓の物性值便覧（鉄龬基礎共同研究会溶鋼・溶滓 部会編) (1972), p. 177

10) H. SPERL: Stahl Eisen, 109 (1989), p. 253

11）岡村祥三, 中島英雅, 丸川雄浄, 姉崎正治, 戸崎泰之, 森 明義, 加藤木健, 市原 清: 鉄と鋼, 71 (1985), p. 1787 